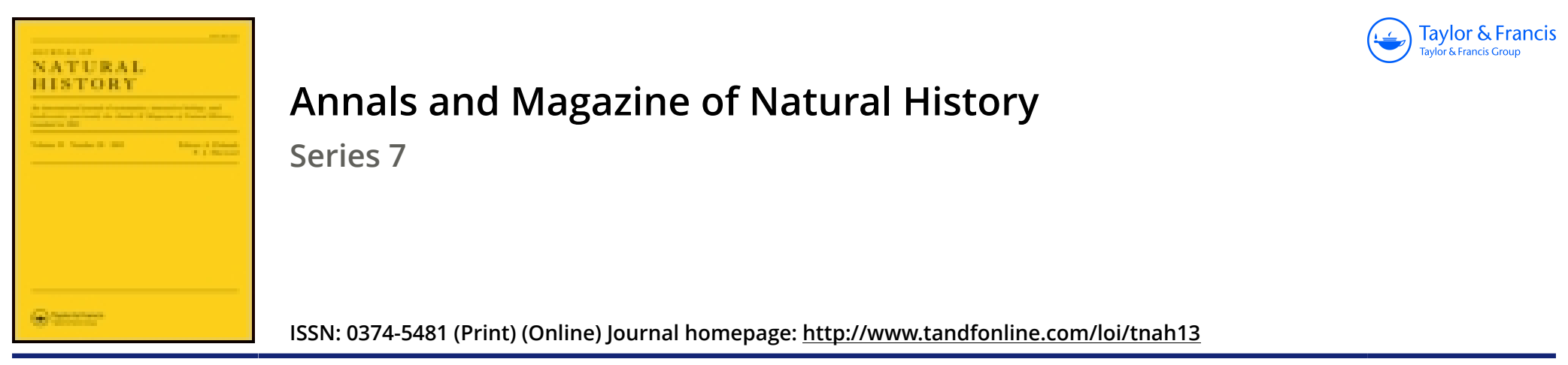

\title{
LV.-On a new dormouse from Asia minor, with remarks on the subgenus "Dryomys."
}

\section{Oldfield Thomas}

To cite this article: Oldfield Thomas (1907) LV.-OOn a new dormouse from Asia minor, with remarks on the subgenus "Dryomys.", Annals and Magazine of Natural History, 20:119, 406-407, DOI: $10.1080 / 00222930709487359$

To link to this article: http://dx.doi.org/10.1080/00222930709487359

册 Published online: 29 Sep 2009.

Submit your article to this journal $\lceil\pi$

Џll Article views: 1

Q View related articles 두 
It frequents the stony kopjes of the Witwatersrand, spending the day in holes under rocks and boulders, and coming out to feed at dusk. I have only once found it lying out in the daytime.

Like other Pronolagi, it frequently returns to the same spot to defreate ; hence its presence in a locality can often be detected by the piles of droppings on the hill-sides. It is a very retiring species, and seems little known among local sportsmen, although it occurs right, up to the outskirts of Johannesburg.

Its short ears, heavy build, and general pose at once recall the European rabbit. It is very fleet on foot; in fact, the "red hare" (a collective name for the members of the genus Pronolagus) is regarded by sportsmen as the fastest of the South-African hares. leveret.

University College, Johannesburg, September 1907.

\section{LV.-On a new Dormouse from Asia Minor, with Remarks on the Subgenus "Dryomys." By OldField Thomas.}

IN 1906 * I formed a special subgenus to contain the dormouse previously known as Eliomys nitedula, Pallas (syn. E.dryas, Schr.), and gave it the name of Dryomys; but I now find that this name is preoccupied $\dagger$, and would propose to replace it by Dyromys, an anagram of the same word.

Since I formed the subgenus there has been discovered the large but nearly related Central-Asian species to which $\mathrm{I}$ applied the specific name angelus, and Mr. Gerrit Miller has drawn my attention to additional points of distinction between

* P. Z. S. 1906, ii. p. 348.

† "Dryomys parvulus, Tschudi, Fauna Peruana, p. 179, lam. xiii. fig. 1." Philippi, An. Mus. Chile, Murideos de Chile, p. 20 (1900).

Although this is, no doubt, merely an exroneous rendering of Drymomys, yet, as it occurs with a specific name attached and a reference both to a description and figure, it seems to be technically too valid as a name to be used again for another animal.

Another of my generic names, Neotomys, was used as a misprint for Nectomys by Wallace some years before I published it, but there the misprinted term was without any mention of a species or reference to a description, and consequently, viewed simply by itself, was a mere nomen nudum, which was not the case with Philippi's Dryomys. 
this group and Eliomys; I am therefore, at his instance, prepared to give it full generic rank.

The new form may be called

\section{Dyromys nitedula phrygius, subsp. $\mathrm{n}$.}

Size about as in subsp. pictus, therefore rather larger than in European nitedula. General colour above a light buffy yellowish, markedly lighter and more yellowish than in either typical nitedula of Southern Russia, Wingei of Greece, or the Persian pictus. Tail lined grey, with a faint tinge of buffy. Bullæ larger than in the European forms.

Dimensions of the type (measured in flesh) :-

Head and body $100 \mathrm{~mm}$.; tail 85 ; hind foot 21 ; ear 14 .

Skull : greatest length 26.7 ; basilar length $20 \cdot 4$; greatest breadth 15 ; nasals 8 ; length of upper molar series $3 \cdot 6$.

Hab. Murad Dagh, Ushak Province, Asia Minor (Mount Dindymus, Phrygia, of classical maps). Altitude $7500^{\prime}$.

Type. Adult male. B.M. no. 5. 10. 6. 1. Original number 37. Collected and presented by W. Griffiths Blackler, Esq. Two specimens.

This pretty dormotse may be distinguished from the other forms of $D$. nitedula by its brighter and yellower colour. The Museum has recently received from Mr. Herbert Sykes a specimen nearly topotypical of Blanford's Myoxus pictus from Central Persia, which might have been the same as the Asia Minor animal, but proves to be a comparatively greyer and less yellowish form. Specimens quite similar to the latter have also been obtained in the Kurrum Valley, N.W. Frontier of India, by Mr. C. H. 'T. Whitehead, thus forming a considerable extension of the eastward range of this type of dormouse.

LVI.-Notes on an "Octopus" with Branching Arms. By Edgar A. SMith, I.S.O., F.Z.S.

[Plate XVIII.]

A collection sent home this year by Mr. R. Gordon Smith from Japan contained a very remarkable specimen of an Octopus with branching arms. It has been presented by him to the British Maseum.

Furcation in the arms of Cephalopods appears to be of 